\title{
Iron and manganese content in groundwater on the northeastern coast of the Buenos Aires Province, Argentina
}

\author{
Silvina Carretero • Eduardo Kruse
}

Received: 28 September 2013/ Accepted: 12 July 2014/Published online: 1 August 2014

(C) Springer-Verlag Berlin Heidelberg 2014

\begin{abstract}
The iron and manganese content in groundwater on the northeastern coast of the Buenos Aires Province, Argentina, was analyzed. Borehole sampling and chemical analyses were performed and evaluated based on the hydrogeological characteristics of the phreatic aquifer located in the coastal barrier, which is the only supply source to the population. Fe concentrations in groundwater fluctuate between 0.03 and $3.5 \mathrm{mg} / \mathrm{L}$, with a mean value of $0.33 \mathrm{mg} / \mathrm{L}$, whereas $\mathrm{Mn}$ varies between 0.03 and $1.20 \mathrm{mg} /$ $\mathrm{L}$, with a mean value of $0.24 \mathrm{mg} / \mathrm{L}$. There is a relationship between the geomorphological environments and the distribution of major ions, except the case of Fe and Mn. The sand that constitutes the aquifer contains pyroxenes, amphiboles, biotite, Fe oxides and hydroxides, and volcanic groundmass stained by hydroxides, all of which are the source of $\mathrm{Fe}$ and $\mathrm{Mn}$ - whose concentrations are unrelated to each other, to $\mathrm{Ph}$ or to Eh due to a state of redox disequilibrium. Possible health risks due to $\mathrm{Fe}$ and Mn excess in water are considered. According to the international guidelines for $\mathrm{Fe}, 38 \%$ of the samples exceed the acceptable values, while $33 \%$ exceed the Argentine standards. As regards $\mathrm{Mn}$, the samples with excess $\mathrm{Mn}$ are 53 and $38 \%$, respectively. Further groundwater quality monitoring and chemical studies are necessary, especially regarding the evolution of $\mathrm{Fe}$ and $\mathrm{Mn}$ contents. To offer an adequate supply of drinking water to the population, it is necessary to remove $\mathrm{Fe}$ and $\mathrm{Mn}$ so that the concentrations are within the drinking water guidelines.
\end{abstract}

\footnotetext{
S. Carretero $(\bowtie) \cdot$ E. Kruse

Facultad de Ciencias Naturales y Museo, Cátedra de Hidrología

General, Consejo Nacional de Investigaciones Científicas y

Técnicas (CONICET), Universidad Nacional de La Plata, $64 \mathrm{n}^{\circ} 3$

(1900) La Plata, Buenos Aires, Argentina

e-mail: scarretero@fcnym.unlp.edu.ar
}

Keywords Drinking water - Iron · Manganese · Coastal aquifer $\cdot$ Argentina

\section{Introduction}

The presence of high concentrations of $\mathrm{Fe}$ and $\mathrm{Mn}$ in groundwater, which is a source of drinking water supply to the population, is a problem which affects different countries, such as New Zealand, the UK (Scotland), India, China, Turkey, and the USA (Ramesh et al. 1995; Daughney 2003; Weng et al. 2007; Zhang et al. 2010; Barnes et al. 2011; Chidambaram et al. 2011; Yuce and Alptekin 2013). In these cases, the concentrations usually exceed the standards required for drinking water.

International organizations have defined screening levels for the compounds dissolved in water for human consumption. The United States Environmental Protection Agency (USEPA) has set a level of $0.3 \mathrm{mg} / \mathrm{L}$ of iron in its secondary standards (USEPA 2003). At that level, there is a discoloration of water, which produces rust stains and organic sludge deposits with $\mathrm{Fe}(\mathrm{OH})_{3}$, which may originate incrustations, causing only an aesthetic impact and not having any effects on health. In its primary standards, the USEPA suggests that the concentration of $\mathrm{Mn}$ in water should not exceed $0.05 \mathrm{mg} / \mathrm{L}$ (USEPA 2004). This recommendation aims at preventing the formation of blackish stains on laundry and the deterioration of fixtures in homes due to insoluble deposits of Mn oxides; besides, it is regarded as more than adequate to protect human health. In turn, the EU has set a threshold limit value for iron of $0.2 \mathrm{mg} / \mathrm{L}$ (EU 1998) and the same value as the USEPA for manganese. The WHO suggests a threshold limit value for manganese of $0.4 \mathrm{mg} / \mathrm{L}$ (WHO 2006). This is a provisional guideline, as there is some evidence of potential risks, but 
according to the WHO the effects on health are limited. In the case of the iron content, it does not set reference values based on health effects, but a value of $2 \mathrm{mg} / \mathrm{L}$ is suggested to prevent iron accumulation in the body (WHO 2006).

The Agency for Toxic Substances and Disease Registry (ATSDR 2000) reports studies carried out both in adults and in children who consumed water with manganese levels above normal, but no conclusive results have been achieved. More current studies (Kondakis et al. 1989;
Wasserman et al. 2006; Bouchard et al. 2007) suggest reconsidering the admissible values in the guidelines.

On the northeast coast of the Buenos Aires Province, Argentina, the only source of drinking groundwater shows limited development and is restricted to a fringe of coastal dunes. The aquifer extends over an area of more than $60 \mathrm{~km}$, and the entire Partido de La Costa district (Fig. 1) has a population of over 70,000 inhabitants (INDEC 2010). In the study area (San Clemente del Tuyú, Argentina), only

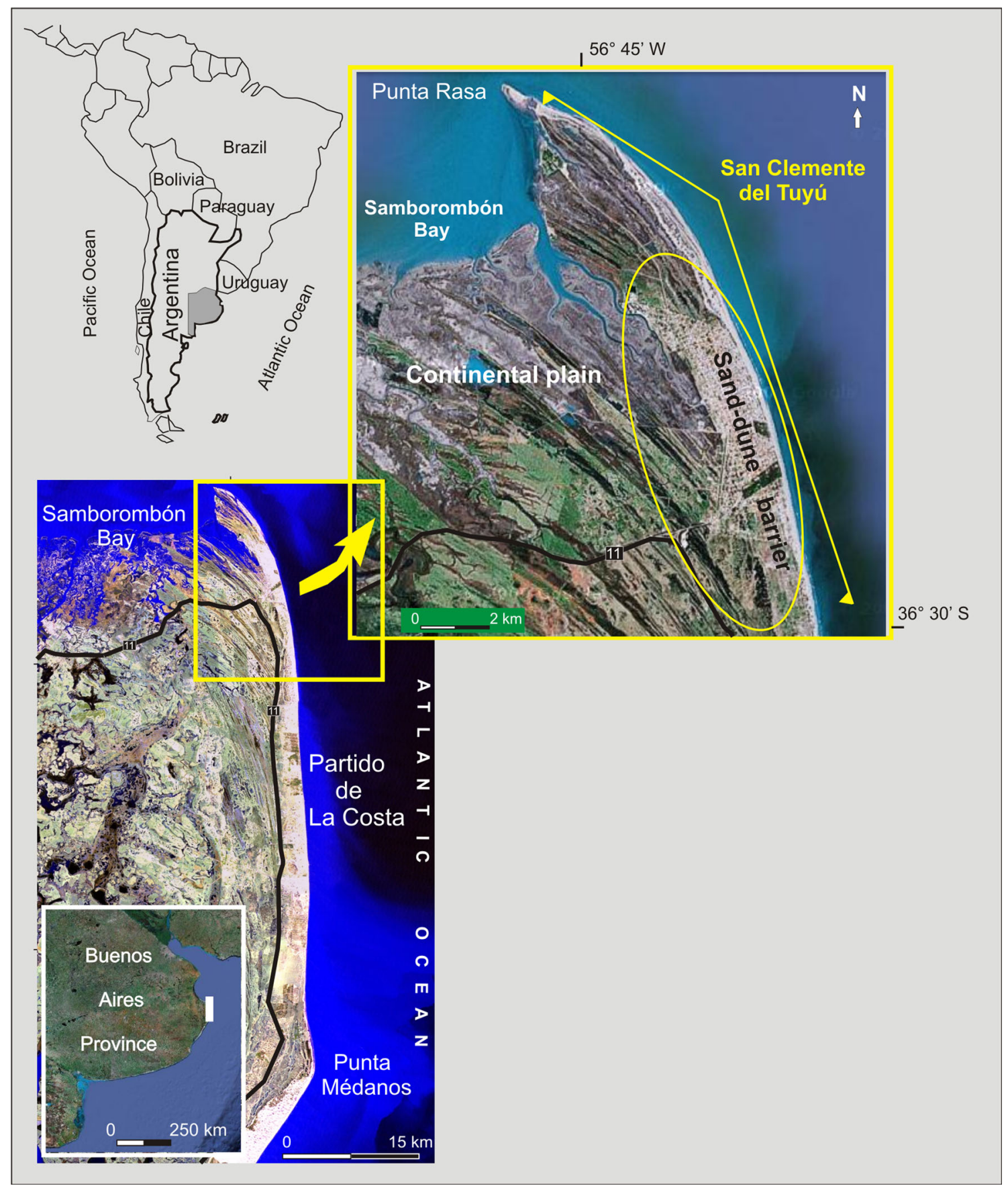

Fig. 1 Location and geomorphological map 
a minor percentage of the households (of the order of 2,500) are supplied by a water network fed by a pumping field located toward the south, out of the urban area. The exploitation is carried out by means of a system of wells located on the coastal barrier; the annual groundwater extraction is approximately $220,000 \mathrm{~m}^{3}$, with a progressively increasing trend (Carretero and Kruse 2010). The population who live in areas excluded from the water supply network satisfy their needs by private extraction with pumps or, in some neighborhoods, the supply of water from municipal wells that is stored in tanks and distributed with no previous treatment. The situation described can be observed throughout the entire eastern coastal region of the Buenos Aires Province, where-with the exception of a few localities with drinking water supply networks restricted to limited sectors-the supply is carried out individually from the aquifer, whose water remains untreated. In the summer, the population of 70,000 inhabitants increases significantly_as the main economic activity in the region is tourism-, which causes the water demand to increase. Therefore, it is of the utmost necessity to have a water supply in accordance with the regulations established.

The results of a regional hydrogeological evaluation (Carretero 2011) made it possible to detect high Fe and Mn contents which exceed those set by the drinking water guidelines. The objective of this work is to analyze the contents of $\mathrm{Fe}$ and $\mathrm{Mn}$ in the groundwater of a coastal sector of the Buenos Aires Province as the basis for a rational use of groundwater and the effective protection of the health of the population.

Iron and manganese in groundwater

The chemistry of iron is relatively complex, as it may have an oxidation state of +2 or +3 . The stability of the ions $\mathrm{Fe}^{2+}, \mathrm{Fe}^{3+}, \mathrm{Fe}(\mathrm{OH})^{2+}$, and $\mathrm{Fe}(\mathrm{OH})^{+}$with respect to $\mathrm{Fe}(\mathrm{OH})_{3}$ and $\mathrm{Fe}(\mathrm{OH})_{2}$ precipitate or colloidal depends on $\mathrm{pH}$, Eh, and the composition of the solution. Certain organic matter, as well as some inorganic matter, may form complexes, which makes their behavior even more complicated (Custodio and Llamas 1996). In general, groundwater only contains dissolved $\mathrm{Fe}^{2+}$ (sometimes $\mathrm{FeOH}^{+}$), and when the $\mathrm{pH}$ is slightly high there is practically no dissolved iron. The concentration of $\mathrm{Fe}^{2+}$ in groundwater varies between 0 and $10 \mathrm{mg} / \mathrm{L}$ and contents higher than $0.5 \mathrm{mg} / \mathrm{L}$ may be harmful or unpleasant in general (Custodio and Llamas 1996).

The iron in water originates from the minerals in igneous rocks, such as pyroxenes, amphiboles, biotite, magnetite, and olivines, which is why most of the iron is in the ferrous oxidation state $\left(\mathrm{Fe}^{2+}\right)$. The ferric state $\left(\mathrm{Fe}^{3+}\right)$ may also be present in the form of magnetite $\left(\mathrm{Fe}_{3} \mathrm{O}_{4}\right)$. Under reducing conditions, if sulfide is present, pyrite, marcasite, and some metastable species - such as mackinawite and greigite-may precipitate; when sulfide is less abundant, siderite may be formed $\left(\mathrm{FeCO}_{3}\right)$. On the other hand, if the environment is oxidizing, sedimentary species such as ferric oxides or oxyhydroxides—such as hematite $\left(\mathrm{Fe}_{2} \mathrm{O}_{3}\right)$, goethite $(\mathrm{FeOOH})$ or other minerals with a similar composition-precipitate. The crystalline structure of the reprecipitated material may be underdeveloped, and they are commonly referred to as ferric hydroxides $\mathrm{Fe}(\mathrm{OH})_{3}$ (Hem 1985). In sandy aquifers, the Fe oxides and oxyhydroxides more commonly found are ferrihydrite, goethite, lepidocrocite, and hematite (Apello and Postma 2007).

The chemistry of manganese is somewhat like that of iron in the sense that both metals participate in redox processes in weathering environments. Manganese, however, presents three possible oxidation states in such environments rather than two $(+2,+3$, and +4$)$ and can form a wide variety of mixed-valence oxides (Hem 1985). However, in general terms, in other environments manganese is found in compounds with oxidation states from +1 to +7 .

In general, manganese occurs as $\mathrm{Mn}^{2+}$, which easily oxidizes to $\mathrm{MnO}_{2}$ and may form stable organic complexes, as iron does. Concentrations are below $0.2 \mathrm{mg} / \mathrm{L}$, rarely above $1 \mathrm{mg} / \mathrm{L}$, and it is most abundant in acid waters (Custodio and Llamas 1996). The source of Mn in water is the minerals in igneous and metamorphic rocks that contain divalent manganese as a minor constituent. It may be found in basalts, olivines, pyroxenes, and amphiboles. In smaller quantities, it also occurs in dolomites and limestones, replacing calcium, whereas in silicates it replaces rhodonite and in carbonates, rhodochrosite (Hem 1985). When it occurs in appreciable quantities, it produces an unpleasant taste in water, which makes its presence noticeable when consumed and its toxic action more easily avoided (Catalán Lafuente 1969; WHO 2006).

\section{Case study}

\section{Hydrogeological conditions}

The study area is the town of San Clemente del Tuyú, in the northern sector of the Partido de La Costa district, Buenos Aires Province, Argentina, and it is located at the northern tip of the Cabo San Antonio (Cape San Antonio; $36^{\circ} 22^{\prime} \mathrm{S}, 56^{\circ} 44^{\prime} \mathrm{W}$; Fig. 1).

San Clemente del Tuyú is located within two environments: a coastal barrier and a continental plain. The continental plain extends to the west of the coastal barrier, with heights below 5 m.a.s.l., whereas the area adjacent to the Bahía de Samborombón (Samborombón Bay) remains 
open to the sea. The coastal ridge runs uninterrupted from Punta Rasa to the south, with a width of $2-4 \mathrm{~km}$, and it is divided into a beach and a dune area. The beach area is rectilinear, between 50 and $150 \mathrm{~m}$ wide, with gentle easttrending slopes. The dunes located to the west of the beach are low and they are fixed by sparse vegetation. The sand is fine grained, increasing in grain size from north to south (Spalletti and Mazzoni 1979). Sand mineralogy includes quartz, plagioclase, potassium feldspar, clayey aggregates originating in the feldspar, volcanic glass, fractions of volcanic groundmass often stained by iron hydroxides, and calcium carbonate corresponding to seashell fragments. The heavy-mineral fraction includes pyroxenes (hypersthene and augite), amphiboles (hornblende), biotite, garnet and scarce epidote, tourmaline, zircon, apatite, and rutile. The opaque mineral fraction is composed of magnetite, hematite, leucoxene and ilmenite, together with the presence of oxyhydroxides (limonites) and iron hydroxides. (Mauriño 1956; Teruggi et al. 1959; Mazzoni 1977). The minerals responsible for the $\mathrm{Fe}$ and $\mathrm{Mn}$ content in groundwater may include pyroxenes, amphiboles, biotite, Fe oxides, and hydroxides, as well as volcanic groundmass stained by iron hydroxides.

A shallow and a deep geohydrological system can be recognized. The deep system, occurring at a depth below 92 m (Consejo Federal de Inversiones 1990), can only be defined as a low-permeability system that includes sand levels containing high-salinity water. The shallow system, which comprises the aquifer of interest, contains a freshwater lens (phreatic aquifer) that has a thickness varying between 4 and $10 \mathrm{~m}$ in the central sector, increasing from north to south and decreasing toward the east up to the interface with seawater and toward the west up to the interface with continental brackish water (Carretero 2011). This unit consists of sands (aeolian) and shelly sands (marine) (Violante and Parker 2000), which overlie a 30-m-thick clayey unit (aquitard/aquiclude) showing intercalations of sandy lenses with high-salinity water. In the coastal barrier, water is of low salinity, mainly of the $\mathrm{Ca}-\mathrm{HCO}_{3}$ type, whereas in the continental plain water is a high-salinity $\mathrm{Na}-\mathrm{Cl}$ type; therefore, geomorphology constitutes a fundamental control on the hydrodynamic and hydrochemical behavior (Carretero et al. 2013).

The climate is characterized by a dry season, which coincides with the cold months of the southern hemisphere (April-September), and a wet season, occurring in the warm months (October-March). The mean annual rainfall fluctuates between 900 and 1,000 mm; $60 \%$ occurs in the months with highest potential evapotranspiration, whereas the highest recharge occurs during the dry season (Carretero and Kruse 2012). The recharge to the hydrogeological system originates exclusively in rainfall surplus.
According to the groundwater flow map (Fig. 2), the coastal barrier is the main recharge area; it flows along a short section and then discharges in two opposite directions, one toward the sea and the other toward the continental plain. The water levels fluctuate between 0.5 and 2.5 m.a.s.l. and an elevated area in the phreatic morphology can be observed in the southern sector between the 1.5 and 2.5 m.a.s.l. curves, coinciding with the highest topographic elevations in the coastal barrier. Freshwater is limited by two interfaces: toward the continent, freshwater/brackish water, and toward the sea, freshwater/ saltwater.

\section{Methodology}

Fieldwork was carried out to recognize and evaluate the geological and geomorphological characteristics, and to interpret their connection with the hydrogeological aspects. At the locality studied, a survey of domestic wells was

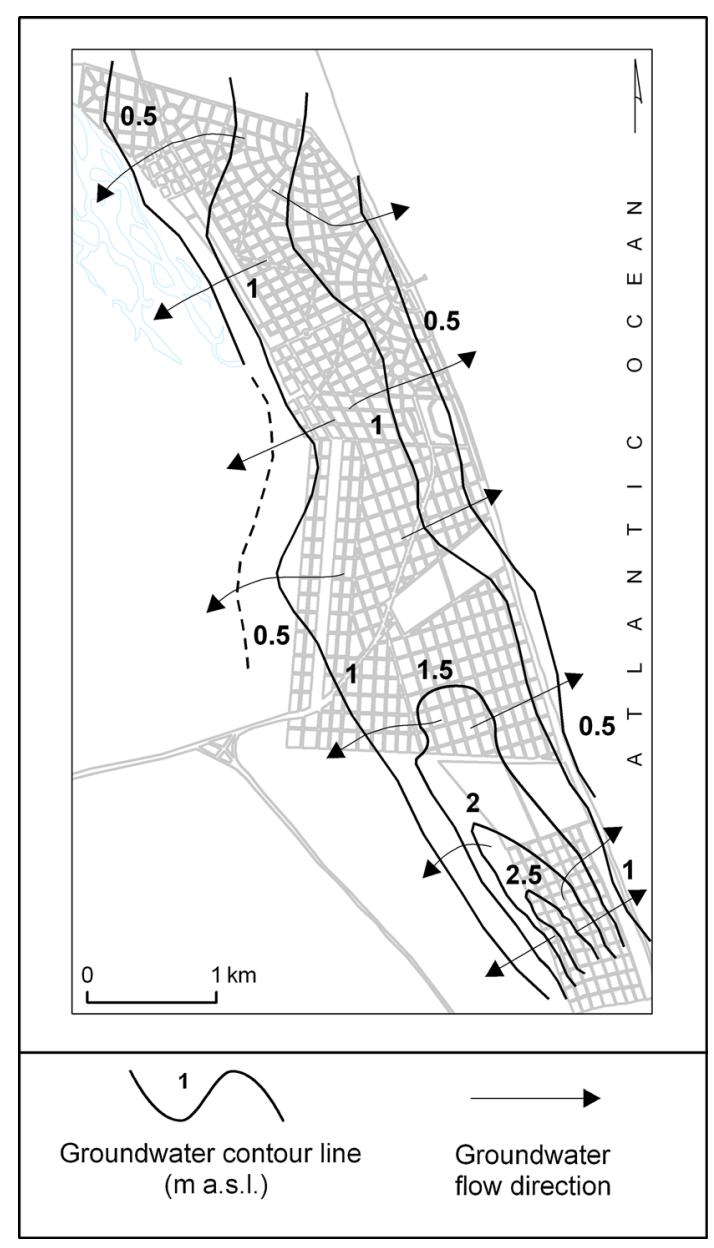

Fig. 2 Isophreatic and groundwater flow map for October 2006 
undertaken in October 2006. The depths of the water table were measured and groundwater samples were obtained using a bailer sampler from 40 wells whose depths range between 3 and $5 \mathrm{~m}$. The $\mathrm{pH}$ and electrical conductivity (EC) values were measured in situ, using a multiparameter water quality meter and a conductivity meter, respectively. The chemical analyses were carried out by the Laboratorio de Ingeniería Sanitaria (LIS; Sanitary Engineering Laboratory) of the UNLP (National University of La Plata). The determination of total dissolved solids (TDS) was carried out gravimetrically (SM-2540 B). The major cations were determined by means of the following methods: Calcium, EDTA Titrimetric SM-3500-Ca B; Sodium, Flame Emission Photometric Method SM-3500-Na B; Potassium, Flame Emission Photometric Method SM-3500-K B; Magnesium, Calculation Method SM-3500-Mg B. The methods used for the major anions were: Bicarbonate, Titrimetric SM-2320 B; Sulfate, Nephelometric, SM-4500SO4-E; Chloride, Mohr SM-4500-Cl. The nitrogen compounds were detected by: Nitrate, Ion-selective electrode SM-4500-NO3-D; Nitrite, Ilosvay von llosva SM-4500 NO2-adaptation; Ammonia, Ion-selective electrode SM4500-NH3-D. Total Fe was analyzed by the SM-3500-Fe B colorimetric method and Mn by the SM-3500M and B persulphate methods. Distribution maps were drawn to assess the areal distribution of these two chemical elements.

The results of the general hydrochemistry of the aquifer showed high concentrations of Fe and Mn. In keeping with the methodology proposed by Daughney (2003) for a similar case, in the attempt to compensate for the lack of direct measurements of Eh and/or dissolved oxygen and/or redox couples, the assumptions and equilibrium equations used by the author were considered. To verify the validity of the method, Eh vs. $\mathrm{pH}$ diagrams were used to plot the laboratory results and assess whether the Fe was actually $\mathrm{Fe}^{2+}$ and the Mn was $\mathrm{Mn}^{2+}$.

\section{Results}

\section{Hydrochemistry}

There are differences in the hydrochemistry depending on the geomorphological environment. In the coastal barrier, the TDS do not exceed $1,500 \mathrm{mg} / \mathrm{L}$ and the bicarbonate content is between 300 and $950 \mathrm{mg} / \mathrm{L}$, with a mean value of $550 \mathrm{mg} / \mathrm{L}$. The concentration of sulfate is below $100 \mathrm{mg} / \mathrm{L}$, whereas the one of chloride is below $400 \mathrm{mg} / \mathrm{L}$. The sodium values are less than $500 \mathrm{mg} / \mathrm{L}$, potassium does not exceed $20 \mathrm{mg} / \mathrm{L}$ and the concentration of calcium varies between 100 and $200 \mathrm{mg} / \mathrm{L}$. Magnesium shows a slightly more heterogeneous distribution, with values below $50 \mathrm{mg} / \mathrm{L}$ in most of the area, while certain restricted sectors range between 50 and $100 \mathrm{mg} / \mathrm{L}$.

The continental plain is characterized by TDS values higher than 1,500 $\mathrm{mg} / \mathrm{L}$, with extremes of 7,600 mg/L. As regards bicarbonates, values between 400 and $800 \mathrm{mg} / \mathrm{L}$ predominate. In certain more reduced areas, there are values above this limit, reaching a maximum of 1,700 $\mathrm{mg} / \mathrm{L}$. Sulfates show values below $200 \mathrm{mg} / \mathrm{L}$ and the chloride concentrations oscillate between 400 and 3,200 mg/L. Calcium has values between 50 and $200 \mathrm{mg} / \mathrm{L}$, with higher concentrations in some areas. Sodium values in general range between 500 and $1,000 \mathrm{mg} / \mathrm{L}$, reaching maximum values of $2,000 \mathrm{mg} / \mathrm{L}$. Potassium is characterized by a maximum value of $65 \mathrm{mg} / \mathrm{L}$, with a predominant distribution between 20 and $40 \mathrm{mg} / \mathrm{L}$. Magnesium ranges between 50 and $100 \mathrm{mg} / \mathrm{L}$, with some areas exceeding this value and a maximum of $200 \mathrm{mg} / \mathrm{L}$.

As regards the nitrogen compounds, the mean nitrate values vary between 9 and $21 \mathrm{mg} / \mathrm{L}$ with a mode of $4 \mathrm{mg} / \mathrm{L}$. There are two points in the semi-urbanized area where concentrations higher than $50 \mathrm{mg} / \mathrm{L}$ (97 and $180 \mathrm{mg} / \mathrm{L}$ ) have been detected. Nitrites show values between 0.03 and 0.01 , with $50 \%$ appearing below the detection limit of $0.01 \mathrm{mg} / \mathrm{L}$. In the case of ammonium, $70 \%$ of the samples have concentrations below $0.03 \mathrm{mg} / \mathrm{L}$ (detection limit), except for three isolated cases with values between 0.09 and $1.5 \mathrm{mg} / \mathrm{L}$. The specific cases with elevated values are attributed to anthropogenic contamination due to the proximity to septic tanks.

Fe concentrations in groundwater fluctuate between 0.03 and $3.5 \mathrm{mg} / \mathrm{L}$, with a mean value of $0.33 \mathrm{mg} / \mathrm{L}$, showing a positive asymmetric distribution, as does $\mathrm{Mn}$, whose extremes vary between 0.03 and $1.20 \mathrm{mg} / \mathrm{L}$, with a mean value of $0.24 \mathrm{mg} / \mathrm{L}$. EC also shows a positive asymmetric distribution, with a general mean of $2,022 \mu \mathrm{S} / \mathrm{cm}$ and maximum and minimum values between 644 and $7,000 \mu \mathrm{S} / \mathrm{cm}$. The $\mathrm{pH}$ varies between 6.7 and 7.9 , with a mean of 7.29 and, unlike the other parameters, a negative asymmetric distribution. The calculated values of Eh also show a negative asymmetric distribution; in the case of $\mathrm{Fe}$, the values oscillate between -0.06 and $0.07 \mathrm{~V}$, with a mode of 0.04. As for $\mathrm{Mn}$, the extremes are between 0.59 and $0.48 \mathrm{~V}$ and the mode is 0.57 (Table 1).

There is a relationship between the spatial distribution of most of the chemical elements and the geomorphology (Carretero et al. 2013); however, Fe and Mn appear to be exceptions. The sandy aquifer is considered to be homogeneous; therefore, in the coastal barrier, a homogeneous distribution of the elements studied could be expected. On the other hand, in the continental plain - an environment that is mainly composed of silty-clayey sediments-, lower concentrations of $\mathrm{Fe}$ and $\mathrm{Mn}$ could also be expected, because adsorption in clay sediments could decrease the 
Table 1 Chemical composition of the groundwater samples and some statistical parameters

\begin{tabular}{|c|c|c|c|c|c|c|c|}
\hline \multirow{2}{*}{$\begin{array}{l}\text { Table } 1 \text { Chemical composition } \\
\text { of the groundwater samples and } \\
\text { some statistical parameters }\end{array}$} & Well \# & $\mathrm{pH}$ & $\mathrm{EC}(\mu \mathrm{S} / \mathrm{cm})$ & $\mathrm{Fe}(\mu \mathrm{S} / \mathrm{cm})$ & $\operatorname{Mn}(\mu \mathrm{S} / \mathrm{cm})$ & Eh Fe (V) & Eh Mn (V) \\
\hline & B7 & 7.30 & 1,440 & 0.10 & 0.03 & 0.02 & 0.55 \\
\hline & 172 & 7.20 & 917 & 0.03 & 0.14 & 0.07 & 0.55 \\
\hline & 103 & 7.30 & 1,601 & 0.03 & 0.04 & 0.05 & 0.55 \\
\hline & $58-1$ & 7.70 & 2,140 & 0.03 & 0.03 & -0.02 & 0.51 \\
\hline & 58 & 7.50 & 672 & $<0.03$ & $<0.03$ & 0.02 & 0.53 \\
\hline & 53 & 7.40 & 1,158 & 0.07 & 0.28 & 0.01 & 0.51 \\
\hline & KK & 7.20 & 1,500 & 0.06 & $<0.03$ & 0.05 & 0.57 \\
\hline & JJ & 7.10 & 3,360 & 0.10 & $<0.03$ & 0.06 & 0.58 \\
\hline & II & 7.20 & 1,263 & 0.03 & 0.28 & 0.07 & 0.54 \\
\hline & $\mathrm{HH}$ & 7.30 & 2,540 & 0.18 & 0.72 & 0.01 & 0.51 \\
\hline & GG & 7.30 & 5,410 & 0.23 & $<0.03$ & 0.001 & 0.55 \\
\hline & $\mathrm{DD}$ & 7.40 & 887 & $<0.03$ & 0.74 & 0.04 & 0.50 \\
\hline & $\mathrm{CC}$ & 7.40 & 1,205 & 0.75 & 1.20 & -0.05 & 0.49 \\
\hline & BB & 7.20 & 7,000 & 0.14 & $<0.03$ & 0.03 & 0.57 \\
\hline & $\mathrm{AA}$ & 6.70 & 2,200 & 3.50 & 0.37 & 0.04 & 0.59 \\
\hline & $\mathrm{Z}$ & 7.90 & 962 & $<0.03$ & $<0.03$ & -0.05 & 0.48 \\
\hline & $\mathrm{Y}$ & 7.40 & 1,777 & 0.30 & 0.17 & -0.02 & 0.52 \\
\hline & $\mathrm{X}$ & 7.30 & 6,350 & 0.11 & $<0.03$ & 0.02 & 0.55 \\
\hline & W & 7.10 & 6,190 & 0.60 & $<0.03$ & 0.01 & 0.58 \\
\hline & $\mathrm{U}$ & 7.20 & 1,641 & 0.32 & 0.18 & 0.01 & 0.54 \\
\hline & $\mathrm{T}$ & 7.20 & 1,180 & 0.35 & 0.06 & 0.01 & 0.56 \\
\hline & $\mathrm{S}$ & 7.00 & 832 & 0.18 & 0.21 & 0.06 & 0.56 \\
\hline & $\mathrm{R}$ & 7.40 & 1,350 & 0.09 & 0.04 & 0.01 & 0.54 \\
\hline & $\mathrm{Q}$ & 7.40 & 1,468 & $<0.03$ & 0.53 & 0.04 & 0.50 \\
\hline & $\mathrm{P}$ & 7.40 & 1,125 & 0.03 & 0.08 & 0.04 & 0.53 \\
\hline & $\mathrm{O}$ & 7.00 & 1,155 & 0.92 & 0.23 & 0.02 & 0.56 \\
\hline & $\mathrm{N}$ & 7.50 & 671 & 0.50 & 0.21 & -0.05 & 0.50 \\
\hline & M & 7.40 & 1,407 & 0.03 & 0.06 & 0.04 & 0.53 \\
\hline & $\mathrm{L}$ & 7.20 & 1,743 & 0.35 & $<0.03$ & 0.01 & 0.57 \\
\hline & $\mathrm{K}$ & 7.60 & 808 & 0.04 & 0.04 & -0.01 & 0.51 \\
\hline & $\mathrm{J}$ & 7.30 & 1,459 & 0.05 & 0.40 & 0.04 & 0.52 \\
\hline & I & 7.70 & 1,578 & 0.16 & 0.04 & -0.06 & 0.50 \\
\hline & $\mathrm{H}$ & 7.40 & 644 & 0.04 & $<0.03$ & 0.03 & 0.54 \\
\hline & G & 7.00 & 1,528 & 0.22 & $<0.03$ & 0.05 & 0.59 \\
\hline & $\mathrm{F}$ & 7.30 & 1,919 & 0.56 & 0.07 & -0.02 & 0.54 \\
\hline & $\mathrm{E}$ & 7.20 & 772 & 0.50 & $<0.03$ & -0.002 & 0.57 \\
\hline & $\mathrm{D}$ & 7.00 & 2,560 & 0.15 & 0.15 & 0.06 & 0.57 \\
\hline & $\mathrm{C}$ & 7.10 & 4,120 & 0.60 & $<0.03$ & 0.01 & 0.58 \\
\hline & B & 7.10 & 3,380 & 0.10 & 0.05 & 0.06 & 0.57 \\
\hline & A & 7.10 & 985 & 0.56 & 0.04 & 0.01 & 0.57 \\
\hline & Median & 7.30 & $1,463.50$ & 0.16 & 0.15 & 0.018 & 0.544 \\
\hline & Mean & 7.29 & $2,022.43$ & 0.33 & 0.24 & 0.017 & 0.542 \\
\hline & Maximum & 7.90 & $7,000.00$ & 3.50 & 1.20 & 0.07 & 0.59 \\
\hline & Minimum & 6.70 & 644.00 & 0.03 & 0.03 & -0.06 & 0.48 \\
\hline & Standard deviation & 0.22 & $1,624.66$ & 0.59 & 0.28 & 0.03 & 0.03 \\
\hline $\begin{array}{l}\text { Theoretical Eh values have been } \\
\text { calculated }\end{array}$ & Mode & 7.4 & & 0.03 & 0.04 & 0.04 & 0.57 \\
\hline
\end{tabular}

Theoretical Eh values have been calculated metal concentration. Nevertheless, the highest concentrations of both $\mathrm{Fe}$ and $\mathrm{Mn}$ occur in the southern sector of the dune. In the case of $\mathrm{Mn}$, the highest values can be found in the central area of the coastal barrier and, in general, they decrease in the direction of the flow (toward the east and west). In the case of $\mathrm{Fe}$, no defined behavior could be 
Fig. 3 Areal distribution of $\mathrm{Fe}$ and $\mathrm{Mn}$

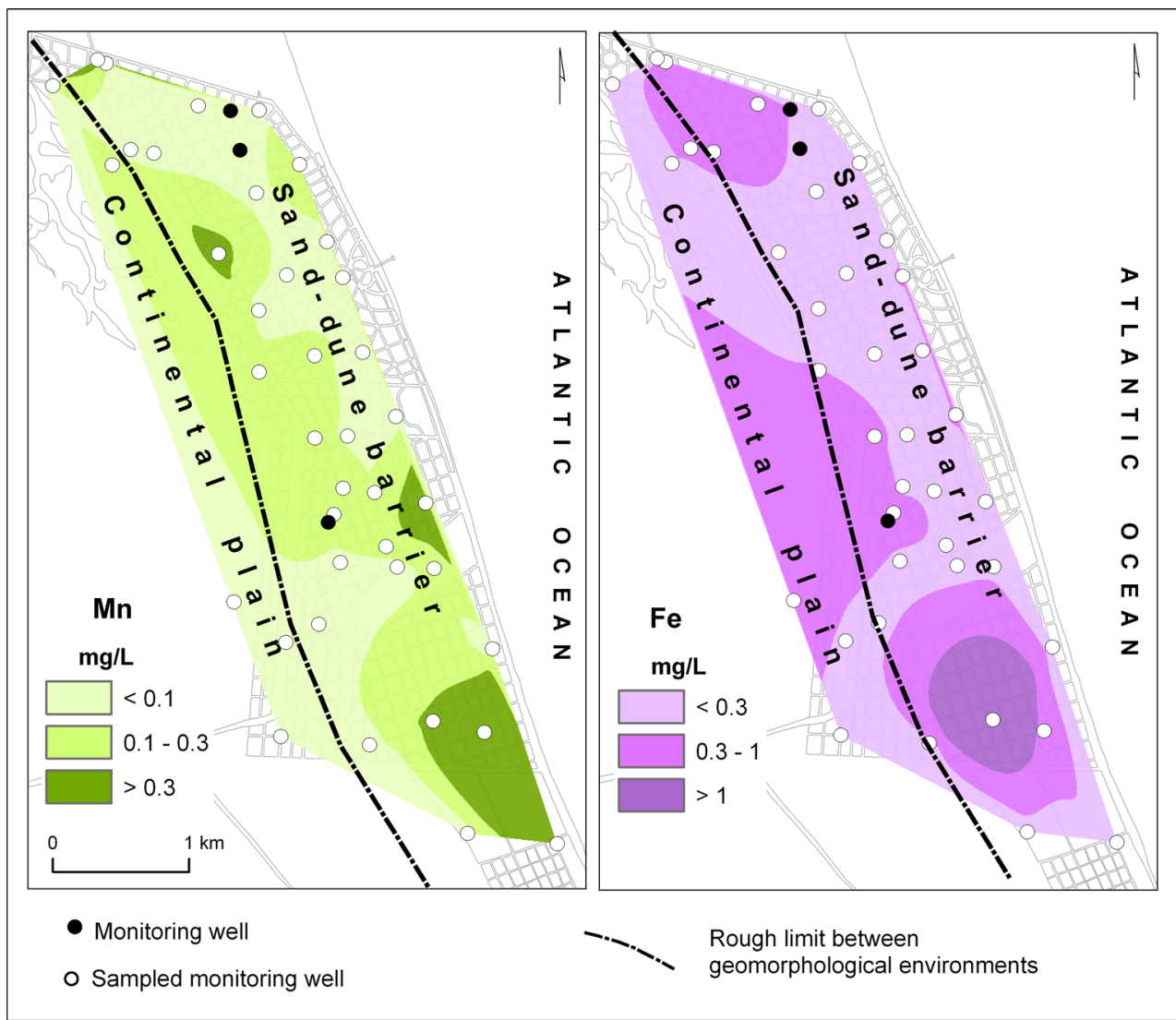

observed and areas with elevated concentrations of Fe can be found in both geomorphological environments (Fig. 3).

$\mathrm{Fe}$ and $\mathrm{Mn}$ and their relationship with $\mathrm{pH}$ and $\mathrm{Eh}$

In the bivariate graph in which the $\mathrm{Fe}$ and Mn concentrations are represented (Fig. 4), it can be observed that there is no correlation between the contents of both elements. According to Langmuir (1997), there are different geochemical processes that may explain this phenomenon. The lack of correlation might be due to the fact that the contents of $\mathrm{Fe}$ and $\mathrm{Mn}$ in the aquifer sand minerals themselves are not homogeneous. It could also reflect the difference in dissolution velocity between $\mathrm{Fe}$ and $\mathrm{Mn}$ related to the groundwater/sediment interaction, resulting in different concentrations of both elements. Another explanation could be based on the differences in oxidation-reduction potential between the samples; for instance, Mn could be reduced-and therefore solubilized-to redox potentials in which $\mathrm{Fe}$ would remain oxidized—and insoluble.

If the relationship between $\mathrm{Fe}$ and $\mathrm{Mn}$ with respect to $\mathrm{pH}$ is analyzed, a correlation is not observed in any of the cases either, as indicated by the $R^{2}$ values in Fig. 5 . However, despite the fact that $\mathrm{pH}$ may affect the quantity of $\mathrm{Fe}$ and $\mathrm{Mn}$ dissolved in groundwater (Hem 1985;

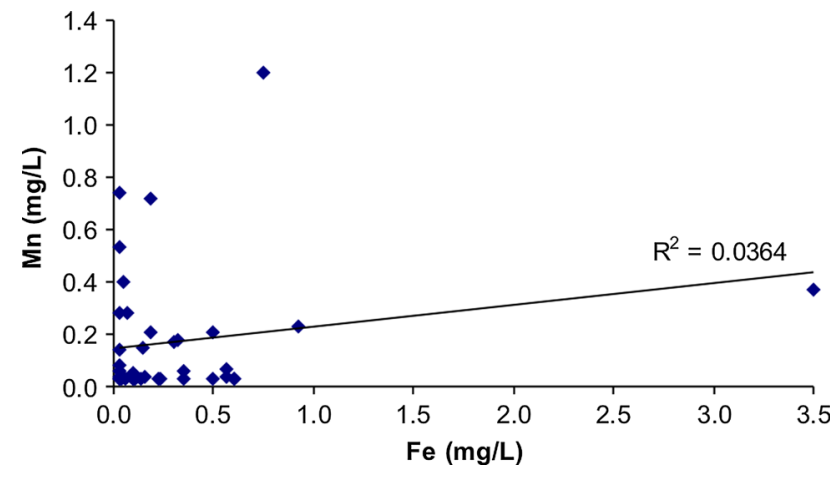

Fig. 4 Mn vs. Fe concentrations, regression line and $\mathrm{R}^{2}$ value

Langmuir 1997), it does not seem to exert a dominant control over the concentrations of the elements analyzed in this case.

Following the methodology used by Daughney (2003), theoretical $\mathrm{Eh}$ values were calculated for $\mathrm{Fe}$ and $\mathrm{Mn}$ (Table 1).

Assuming that water is in equilibrium with the surrounding aquifer materials, the $\mathrm{Fe}$ concentration in solution is buffered by the dissolution of an $\mathrm{Fe}^{3+}$ mineral, such as an iron oxyhydroxide. If it were represented by $\mathrm{Fe}(\mathrm{OH})_{3}$, its reduction would be described by means of reaction (1), where $\mathrm{e}^{-}$represents the electron: 


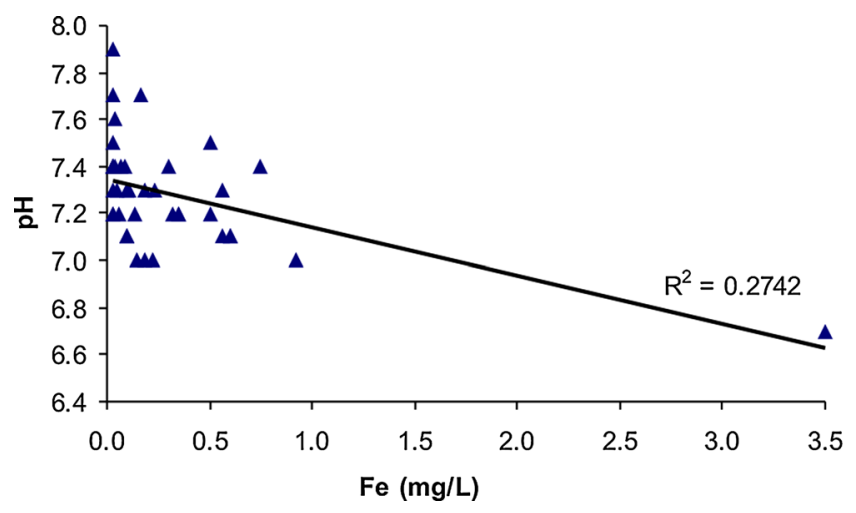

Fig. $5 \mathrm{Fe}$ and $\mathrm{Mn}$ vs. $\mathrm{pH}$, regression line and $R^{2}$ value

$\mathrm{Fe}(\mathrm{OH})^{3}+3 \mathrm{H}^{+}+\mathrm{e}^{-} \rightarrow \mathrm{Fe}^{2+}+3 \mathrm{H}_{2} \mathrm{O}$

In equilibrium, the redox potential (Eh) and $\mathrm{Fe}^{2+}$ concentration are related by means of reaction (2),

$\mathrm{Eh}^{\mathrm{Fe}}=E^{0}+\frac{R T}{n F} \operatorname{In} \frac{\left[\mathrm{H}^{+}\right]^{3}}{\left[\mathrm{Fe}^{2+}\right]}$

where $\mathrm{Eh}^{0}$ is the standard potential for the partial reaction (in this case, $0.975 \mathrm{~V}$; Daughney 2003), $R$ is the gas constant, $T$ is the temperature, $n$ is the number of electrons transferred in the reaction, $F$ is the Faraday constant and the values between brackets represent the activity of the species. If it is assumed that all of the dissolved $\mathrm{Fe}\left(\mathrm{Fe}_{\mathrm{s}}\right)$ exists as $\mathrm{Fe}^{2+}$, by hydrolysis the concentration of $\mathrm{Fe}^{2+}$ may be calculated according to (3),

$\left[\mathrm{Fe}^{2+}\right]=\left[\mathrm{Fe}_{s}\right] \frac{\left[\mathrm{H}^{+}\right]}{K\left[\mathrm{H}^{+}\right]}$

where $\mathrm{Fe}_{\mathrm{s}}$ is the $\mathrm{Fe}$ concentration in $\mathrm{mol} / \mathrm{L}$ and $K$ is the thermodynamic stability constant which describes the formation of $\mathrm{FeOH}^{+}$from $\mathrm{Fe}^{2+}$. Following Langmuir (1997), it is assigned a value of $K=10^{-10.1}$.

On the basis of the equations described, it is possible to calculate a theoretical value for each water sample collected, using $\mathrm{Fe}_{\mathrm{s}}$ and $\mathrm{pH}$ (Daughney 2003; Table 1).

Likewise, if groundwater is in redox equilibrium with respect to $\mathrm{Mn}$, the concentration of dissolved $\mathrm{Mn}$ is buffered by a reducing solution of a Mn mineral, most probably $\mathrm{MnO}_{2}$ (4):

$\mathrm{MnO}_{2}+4 \mathrm{H}^{+}+2 \mathrm{e}^{-} \rightarrow \mathrm{Mn}^{2+}+2 \mathrm{H}_{2} \mathrm{O}$

If it is also assumed that $\mathrm{Mn}_{\mathrm{s}}$ exists entirely as $\mathrm{Mn}^{2+}$, it is possible to calculate a theoretical value for redox potential from the concentrations of dissolved $\mathrm{Mn}$ and the $\mathrm{pH}$ (Table 1$). E^{0}$ is assumed to be $1.23 \mathrm{~V}$ for this reaction (Daughney 2003).

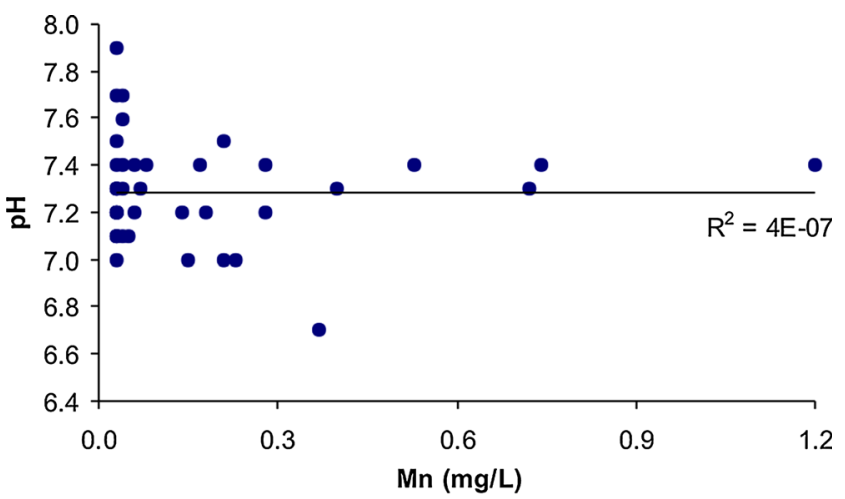

$\mathrm{Eh}^{\mathrm{Mn}}=E^{0}+\frac{R T}{n F} \operatorname{In} \frac{\left[\mathrm{H}^{+}\right]^{4}}{\left[\mathrm{Mn}^{2+}\right]}$

To verify whether the $\mathrm{Fe}$ and $\mathrm{Mn}$ in the samples actually existed as $\mathrm{Fe}^{2+}$ and $\mathrm{Mn}^{2+}$, respectively, and if the concentrations were consistent with this fact, Eh vs. $\mathrm{pH}$ diagrams were used (Hem 1985). The results show that, according to the diagrams, $\mathrm{Fe}$ and $\mathrm{Mn}$ are, in fact, in $\mathrm{a}+2$ oxidation state (Fig. 6).

The study case shows values similar to the ones found by Daughney (2003) for New Zealand, in which the author concludes that groundwater is not in redox equilibrium as the redox potentials (Eh Fe and Eh Mn) calculated on the basis of the $\mathrm{Fe}$ and $\mathrm{Mn}$ concentrations do not coincide, as shown in Fig. 7a. A correlation between the Eh values and the concentrations of soluble $\mathrm{Fe}$ and $\mathrm{Mn}$ cannot be observed either (Fig. 7b).

Groundwater regulations

The Código Alimentario Argentino (CAA; Argentine Food Code) sets the standards at $0.3 \mathrm{mg} / \mathrm{L}$ for iron and $0.10 \mathrm{mg} / \mathrm{L}$ for manganese (Ministerio de Agricultura, Ganadería, Pesca y Alimentos 2007). The iron content is similar to the one suggested by the USEPA, but it tolerates twice as much manganese as the international guidelines.

The spatial distribution of the concentrations of these elements according to their admissible values for human consumption was analyzed. In the case of iron, the limits set by the CAA and the EU were considered. As can be seen in Fig. 8, there is not much difference between the areas with levels above the admissible values according to both guidelines, as the CAA suggests $0.3 \mathrm{mg} / \mathrm{L}$ and the $\mathrm{EU}$ suggests $0.2 \mathrm{mg} / \mathrm{L}$. In percentages, according to the EU, the Fe concentration in $38 \%$ of the samples exceeds the set levels; the value decreases to $33 \%$ according to the CAA standards. 

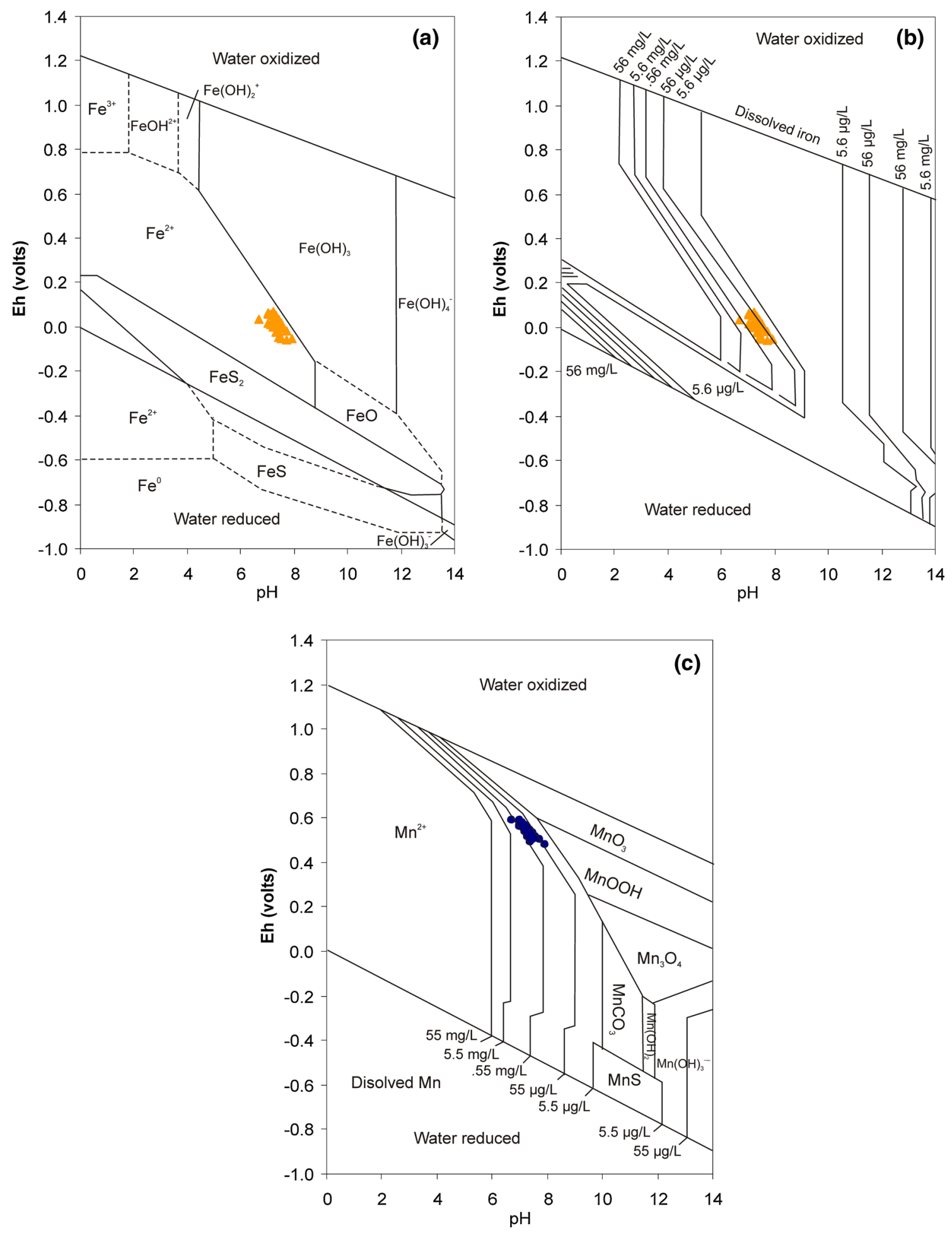

Fig. 6 a Fields of stability for solid and dissolved forms of iron as a function of $\mathrm{Eh}$ and $\mathrm{pH} ; \mathbf{b}$ equilibrium activity of dissolved iron as a function of Eh and $\mathrm{pH}$; $\mathbf{c}$ fields of stability of manganese solids and

The contrast is evident when the comparison is made in the case of manganese, as the CAA sets $0.1 \mathrm{mg} / \mathrm{L}$ as an acceptable value, whereas the international guidelines of equilibrium dissolved manganese activity as a function of $\mathrm{Eh}$ and $\mathrm{pH}$. Graphs taken from Hem (1985)

both the EU and the USEPA suggest it should not exceed $0.05 \mathrm{mg} / \mathrm{L}$. In Fig. 8, it may be observed that practically the whole study area shows manganese values in excess of the 
(b)

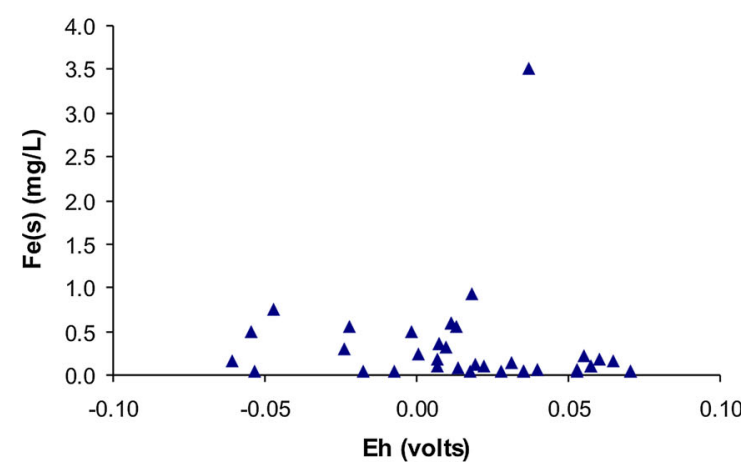

Fig. 7 a Theoretical Eh values calculated from $\mathrm{pH}$ for different concentrations of dissolved $\mathrm{Fe}$, assuming an equilibrium with respect to $\mathrm{Fe}(\mathrm{OH})_{3}$, and for different concentrations of dissolved $\mathrm{Mn}$,
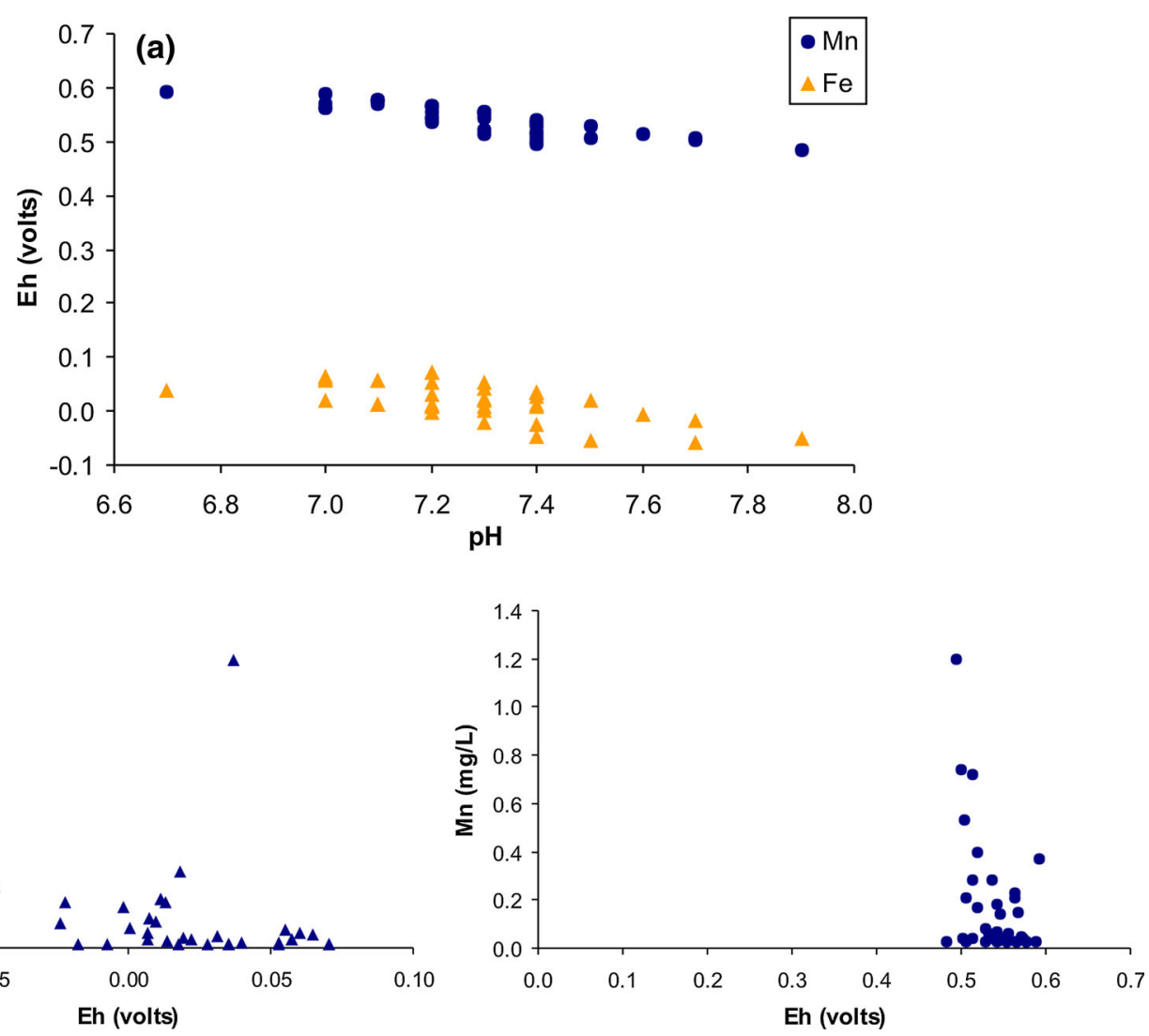

assuming an equilibrium with respect to $\mathrm{MnO}_{2}$; b theoretical Eh calculated vs. Fe and Mn

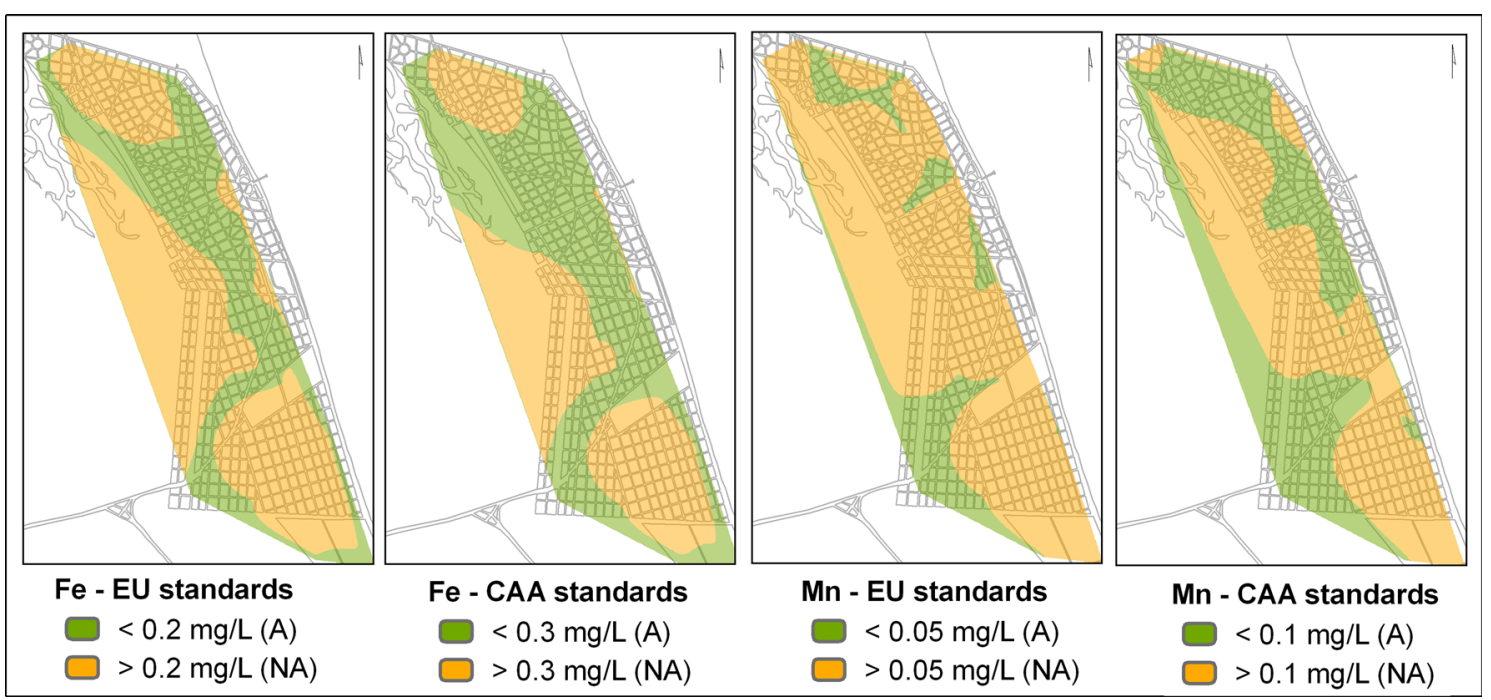

Fig. 8 Distribution map of Fe and Mn according to Argentine and international standards. $A$ indicates areas with acceptable concentrations for human consumption and $N A$ indicates areas with concentrations in excess of the guidelines set

international guidelines, which represents $53 \%$ of the samples, whereas if the CAA values are considered, the area decreases considerably, resulting in $38 \%$ of the sampled wells with values exceeding the national standards.
Most of the inhabitants consume water with $\mathrm{Fe}$ and $\mathrm{Mn}$ contents above the guidelines considered. Consumers admit to problems concerning the taste and color of the water they drink, but as in many cases their incomes are 
low, resorting to alternative sources-such as bottled water-is not economically viable. They also describe problems regarding incrustations in pipes and dark or yellowish stains in fixtures and laundry.

\section{Discussion}

The source of $\mathrm{Fe}$ and $\mathrm{Mn}$ in groundwater is the igneous rock minerals for the former and igneous and metamorphic rock minerals for the latter (Hem 1985). Some of these minerals are oxides in which $\mathrm{Fe}$ exists as $\mathrm{Fe}^{3+}$ (i.e., magnetite) and $\mathrm{Mn}$ as $\mathrm{Mn}^{4+}$ (i.e., pyrolusite) and they need a reducing environment to transfer to water with oxidation state +2 . On the other hand, these elements also appear in some minerals in their divalent forms, especially in silicates (i.e., amphiboles, pyroxenes, olivines and micas; Hem 1985).

In the study area, the source minerals for Fe and Mn can be found in the sediments that constitute the aquifer. The parent materials of the sand along the coast of Buenos Aires are intermediate-basic and felsic volcanic rocks (Teruggi et al. 1959) containing pyroxenes, amphiboles, biotite, Fe oxides and hydroxides, as well as volcanic groundmass stained by iron hydroxides (Mauriño 1956; Teruggi et al. 1959; Mazzoni 1977), which could readily explain the presence of $\mathrm{Fe}$ and $\mathrm{Mn}$ in $\mathrm{a}+2$ oxidation state. The high contents of $\mathrm{Fe}$ and $\mathrm{Mn}$ in groundwater could be associated with the presence among the mineralogical components of the sand of an important magnetic fraction, which includes colorless, brown and black glass with magnetite inclusions and generalized hematization, as well as independent crystals of magnetite with replacement by hematite.

If the aquifer is under reducing conditions, it is possible for the $\mathrm{Fe}$ and $\mathrm{Mn}$ in +2 oxidation state to originate from the reduction of an Fe oxide in a +3 oxidation state or a Mn oxide in the +4 oxidation state. But it could also be explained by the presence of the minerals mentioned above, in which case the $\mathrm{Fe}$ and $\mathrm{Mn}$ are already in a +2 oxidation state, transferring directly to water by dissolution. The ferromagnesian minerals like pyroxenes, amphiboles, garnets, and biotite could be altered to chlorite $((\mathrm{Mg}$, $\left.\mathrm{Fe})_{3}(\mathrm{Si}, \quad \mathrm{Al})_{4} \mathrm{O}_{10}(\mathrm{OH})_{2} \cdot(\mathrm{Mg}, \quad \mathrm{Fe})_{3}(\mathrm{OH})_{6}\right)$ which could transform into $\mathrm{Fe}$ and $\mathrm{Ti}$ oxides like ilmenite $\left(\mathrm{Fe}^{2+} \mathrm{Ti}^{4+-}\right.$ $\mathrm{O}_{3}$ ). Olivine could also decompose, forming Fe oxides and hydroxides. The alteration of some oxides such as magnetite and ilmenite into oxyhydroxides is also possible.

It has been verified that $\mathrm{Fe}$ and $\mathrm{Mn}$ appear in $\mathrm{a}+2$ oxidation state. Besides, it has been observed in situ that the groundwater (colorless), once extracted and after a short period of time in contact with oxygen, the coloring becomes reddish and blackish/reddish, which is evidence of the transformation of $\mathrm{Fe}$ and $\mathrm{Mn}$ compounds to their oxidized forms, probably hydroxides.

Even though it could be considered that the elevated bicarbonate content detected may be produced by the oxidation of the organic matter at the expense of the reduction of nitrates and $\mathrm{Fe}$ and $\mathrm{Mn}$ oxides and hydroxides-creating a reducing environment with the presence of $\mathrm{Fe}$ and $\mathrm{Mn}$ solutions and probably of nitrogen or ammonia (Barbagallo et al. 1994)_in the area there is practically no soil development, as the soil is sandy and excessively drained. As regards the paleosols, the existence of an incipient level between the sand of marine origin and the aeolian sand composing the coastal barrier could be inferred by the presence of plant detritus remains. In the chemical analyses, the concentrations of nitrogen compounds detected, including ammonium, have not been high, except for specific cases of anthropogenic pollution. Despite the fact that there are sectors with elevated bicarbonate contents, there is no correlation with the Fe and Mn contents.

In keeping with the methodology proposed by Daughney (2003), the relationship among $\mathrm{Fe}, \mathrm{Mn}, \mathrm{Eh}$, and $\mathrm{pH}$ was analyzed on the basis of a supposed equilibrium between groundwater and the materials composing the aquifer; the results show a lack of correlation among $\mathrm{Fe}$ and $\mathrm{Mn}$, and the relationships Fe vs. $\mathrm{pH}$ and $\mathrm{Mn}$ vs. Eh. These results coincide with those obtained for New Zealand (Daughney 2003). In the case of Eh vs. pH, it can be concluded that there is a state of redox disequilibrium, as the values do not coincide and, according to the author cited, this is due in part to the sluggish nature of electron transfer reactions and the role of microbial catalysis. The author also emphasizes that the redox disequilibrium observed in New Zealand indicates that chemical speciation models will not reliably predict Fe and Mn concentrations, which would also be valid for the coast of Buenos Aires.

The situation described is frequent in other aquifers; for instance, Lindhurg and Runnells (1984) verify it using the same methodology in over 600 samples from different localities, in which the oxidation-reduction reactions are not generally in equilibrium. These authors state that if all the computed Eh values agree, the sample is probably in redox equilibrium. Disagreement among the computed Eh values suggests that the system is at disequilibrium and that there is no single master Eh value.

\section{Conclusions}

On the coast of the Buenos Aires Province, the Fe and Mn contents in the groundwater for drinking water supply have values that in general may reach 3.5 and $1.2 \mathrm{mg} / \mathrm{L}$, 
respectively, with mean values of $0.33 \mathrm{mg} / \mathrm{L}$ for $\mathrm{Fe}$ and $0.24 \mathrm{mg} / \mathrm{L}$ for $\mathrm{Mn}$. The values above the admissible levels for human consumption extend over an area that includes most of the aquifer located in the coastal dunes.

The Fe and Mn concentrations derived from pyroxenes, amphiboles, biotite, Fe oxides and oxyhydroxides, as well as the volcanic groundmass stained by iron hydroxides occurring in the sand of the dunes that constitute the phreatic aquifer being exploited, are unrelated to each other or to the $\mathrm{pH}$ or Eh, due to a state of redox disequilibrium. Although there is a relationship between geomorphology and the distribution of major ions, it is not observed in the case of $\mathrm{Fe}$ and $\mathrm{Mn}$.

The population consumes water with $\mathrm{Fe}$ and $\mathrm{Mn}$ values higher than the admissible standards, which is why it is suggested that processes of $\mathrm{Fe}$ and $\mathrm{Mn}$ removal should be developed to guarantee an adequate quality of the water for public supply.

The first urban settlements in the region date from the middle 20th century; therefore, several generations have consumed this type of water. It is necessary to carry out an analysis of the population at a local scale to assess the presence of effects on health, considering the consumption of water with high contents of $\mathrm{Fe}$ and Mn.

In Argentina, the acceptable value of $\mathrm{Fe}$ is similar to the international standards, whereas in the case of $\mathrm{Mn}$, the admissible concentration is twice as high; as a result, the section fit for consumption increases in areal extension. It would be convenient to carry out a revision and adaptation of the CAA to the international guidelines as regards the admissible limits of $\mathrm{Mn}$ in drinking water.

Acknowledgments The authors are indebted to the Consejo Nacional de Investigaciones Científicas y Técnicas (Nacional Council for Scientific and Technological Research) of Argentina for financially supporting this study by means of the Grant PIP 0403/13. We would also like to thank Lic. Marcos Macchioli Grande for his contribution to this work, as well as the reviewers and editors for the valuable comments that improved the quality of the manuscript.

\section{References}

Apello CAJ, Postma D (2007) Geochemistry, groundwater and pollution. A.A Balkema publishers, Leiden

ATSDR (2000) Toxicological profile for manganese. http://www. atsdr.cdc.gov/toxprofiles/tp151.html. Accessed 23 March 2013

Barbagallo J, Vizcaíno A, González Arzac R, Campos Alfonso F (1994) Hidroquímica de acuíferos costeros, San Clemente del Tuyú. Provincia de Buenos Aires, República Argentina. Águas Subterrâneas: Suplemento VIII Congreso Brasileiro de Águas Subterrâneas. http://www.aguassubterraneas.abas.org.asubterra neas/issue/view/1193. Accessed 17 March 2014

Barnes NA, Kehew AE, Krishnamurthy RV, Koretsky CM (2011) Redox evolution in glacial drift aquifers: role of diamicton units in reduction of Fe(III). Environ Earth Sci 62:1027-1038. doi:10. 1007/s12665-010-0590-7
Bouchard M, Laforest F, Vandelac L, Bellinger D, Mergler D (2007) Hair manganese and hyperactive behaviours: pilot study of school age children exposed through tap water. Environ Health Perspect 115:122-127

Carretero S (2011) Comportamiento hidrológico de las dunas costeras en el sector nororiental de la provincia de Buenos Aires [Hydrological behavior in the Northeastern coast of Buenos Aires province] Doctoral Thesis. Facultad de Ciencias Naturales y Museo, La Plata. Argentina. http://sedici.unlp.edu.ar/handle/ 10915/4918. Accessed 15 February 2013

Carretero S, Kruse E (2010) Areal exploitation of groundwater in coastal dunes, Buenos Aires. Argentina. In: Paliwal BS (ed) Global groundwater resources and management. Scientific Publishers (India), Jodhpur, pp 385-398

Carretero S, Kruse E (2012) Relationship between precipitation and water-table fluctuation in a coastal dune aquifer: northeastern coast of the Buenos Aires province, Argentina. Hydrogeol J 20:1613-1621. doi:10.1007/s10040-012-0890-y

Carretero S, Dapeña C, Kruse E (2013) Hydrogeochemical and isotopic characterisation of groundwater in a sand-dune phreatic aquifer in the northeastern coast of the province of Buenos Aires, Argentina. Isot Environ Health Stud 49(3):399-419. doi:10. 1080/10256016.2013.776557

Catalán Lafuente JG (1969) Química del agua. Blume, Madrid

Chidambaram S, Karmegam U, Prasanna MV, Sasidhar P, Vasanthavigar M (2011) A study on hydrochemical elucidation of coastal groundwater in and around Kalpakkam region, Southern India. Environ Earth Sci 64:1419-1431. doi:10.1007/s12665011-0966-3

Consejo Federal de Inversiones (1990) Evaluación del Recurso Hídrico Subterráneo de la Región Costera Atlántica de la Provincia de Buenos Aires Región I Punta Rasa-Punta Médanos.Informe Final. Tomo I Hidrología Subterránea. CFI, Buenos Aires

Custodio E, Llamas MR (1996) Hidrología Subterránea. Omega, Barcelona

Daughney CJ (2003) Iron and manganese in New Zealand's groundwater. J Hydrol (NZ) 42(1):11-26

EU (1998) Drinking Water Directive. Council Directive 98/83/EC on the quality of water intented for human consumption. http:// eurlex.europa.eu/LexUriServ/LexUriServdo?uri=OJ:L:1998:330: 0032:0054:EN:PDF. Accessed 17 June 2013

Hem JD (1985) Study and Interpretation of the Chemical Characteristics of Natural Water. Third Edition US Geological Survey Water-Supply Paper 2254. United States Government Printing Office, USA

INDEC (2010) Censo Nacional de Población, Hogares y Viviendas. http://www.censo2010.indec.gov.ar/. Accessed 23 July 2012

Kondakis XG, Makris N, Leotsinidis M, Prinou M, Papapetropoulos T (1989) Possible health effects of high manganese concentrations in drinking water. Arch Environ Health 44:175-178

Langmuir D (1997) Aqueous environmental geochemistry. Prentice Hall, New Jersey

Lindhurg RE, Runnells DD (1984) Ground water redox reactions: an analysis of equilibrium state applied to Eh measurements and geochemical modeling. Science 225:925-927

Mauriño V (1956) Los sedimentos psamíticos actuales de la región costera comprendida entre Faro Recalada y Faro Monte Hermoso. LEMIT Serie II 61:1-35

Mazzoni MM (1977) Características composicionales de la fracción pesados de arenas de playa frontal del litoral atlántico bonaerense. Revista de la Asociación Argentina de Mineralogía, Petrología y Sedimentología. Tomo III no. 3-4:73-91

Ministerio de Agricultura, Ganadería, Pesca y Alimentos (2007) Código Alimentario Argentino. Decreto 815/1999 y 4238/1968, resolución 68/2007 y 196/2007. http://www.alimentosargentinos. gov.ar/contenido/marco/marco2.php. Accessed 22 May 2013 
Ramesh R, Shiv Kumar K, Eswaramoorthi S, Purvaja GR (1995) Migration and contamination of major and trace elements in groundwater of Madras City, India. Environ Geol 25:126-136

Spalletti LA, Mazzoni MM (1979) Caracteres granulométricos de arenas de playa frontal, playa distal y médano litoral atlántico bonaerense. Rev Asoc Geol Arg 34:12-30

Teruggi ME, Chaar E, Remiro JR, Limousin T (1959) Las arenas de la costa de la provincia de Buenos Aires entre Cabo San Antonio y Bahía Blanca. LEMIT Serie II 77:1-37

USEPA (2003) National secondary drinking water regulations. USEPA 816-F-03-016. http://www.U.S.EPA.gov/safewater/con taminants/index.html\#sec. Accessed 20 May 2013

USEPA (2004) Drinking water health advisory for manganese. http:// www.U.S.EPA.gov/safewater/ccl/pdfs/reg_determine1/support_ cc1_magnese_dwreport.pdf. Accessed 20 May 2013

Violante RA, Parker G (2000) El Holoceno en las regiones marinas y costeras del nordeste de la provincia de Buenos Aires. Rev Asoc Geol Arg 55:337-351

Wasserman GA, Liu X, Parvez F, Ahsan H, Levy D, Factor-Litvak P et al (2006) Water manganese exposure and children's intellectual function in Araihazar, Bangladesh. Environ Health Perspect 114:124-129

Weng H-X, Qin Y-Ch, Chen X-H (2007) Elevated iron and manganese concentrations in groundwater derived from the Holocene transgression in the Hang-Jia-Hu Plain, China. Hydrogeol J 15:715-726

WHO (2006) Guidelines for drinking water quality. Final task group meeting. WHO Press. World Health Organization, Geneva

Yuce G, Alptekin C (2013) In situ and laboratory treatment tests for lowering of excess manganese and iron in drinking water sourced from river-groundwater interaction. Environ Earth Sci. doi:10.1007/s12665-013-2343-x

Zhang Y, Sun J, Huang G, Jing J, Liu J, Zhang Y (2010) Natural background levels of $\mathrm{Fe}$ and $\mathrm{Mn}$ in groundwater of Pearl River Delta. International conference on digital manufacturing and automation 978-0-7695-4286-7/10. IEEE Computer Society. pp 972-997. doi:10.1109/ICDMA.2010.288. Accessed 6 April 2013 